\title{
Język przekładu w oczach polskich przekładoznawców
}

\section{Urszula Dąmbska-Prokop}

Uniwersytet Jagielloński w Krakowie juprodamb@gmail.com

Streszczenie

Wkład polskich przekladoznawców w myśl o tlumaczeniu, zwłaszcza $w$ ostatnich ponad trzydziestu latach, zastugiwałby na syntetyczne opracowanie. Tutaj wybrana została, spośród „,pewników tlumaczenia” (zob. Chesterman 1997), „obcość” w przektadzie, określana też jako „egzotyzacja” lub ,światto w języku i kulturze”. Zachowanie obcości stanowi, wedtug Antoine Bermana, akt etyczny tlumacza, co Autorka podziela. Jej zdaniem, dwa sposoby thumaczenia, fragmentu powieści Gustawa Flauberta Madame Bovary oraz fragmentu powieści Raymonda Queneau Zazie dans le métro, należa, wedtug rozróżnienia zaproponowanego przez Zygmunta Grosbarta, pierwszy do thumaczeń raczej ,nieśmiatych”, drugi - do „zuchwatych”.

Slowa kluczowe: pewniki w thumaczeniu, obcość w przekładzie, światlo międzyjęzykowe, przekład nieśmiaty / zuchwaty.

\section{Abstract}

Language of Translation as Seen by Polish Translation Scholars

What Polish translators brought into the theory of translation in the last thirty years merits a synthetic presentation. Here we chose, amidst the "memes of translation" (cf. Chesterman 1997), the issue of "strangeness" in translation, also termed "exotisation" or "light in language and culture". To preserve strangeness is for Antoine Berman an essentially ethical act in translation, the position shared by the author. For her, two ways of translating a passage from Gustave Flaubert's novel Madame Bovary, and a passage from Raymond Queneau's novel Zazie dans le metro, represent, in the typology proposed by Zygmunt Grosbart, a type of 'careful' translation and the 'brave' translation type, respectively.

Keywords: memes in translation, strangeness in translation, light in language, careful/brave translation 
Ostatnio ukazało się w Polsce wiele cennych rozpraw i artykułów zajmujących się językiem przekładu. Wprawdzie, jak się wyraził Zygmunt Grosbart, nie można wskazać jednej „użytecznej” koncepcji tłumaczenia, jednak należy przytaknąć głoszonej przez niego tezie o „celowości spożytkowania użytecznych elementów wszelkich koncepcji, teorii czy prądów kulturowych i literackich, nawet tych, które generalnie rzecz biorąc nie przystają do naszego dzisiejszego myślenia" (Grosbart 1998: 54). Tym bardziej więc warto zwrócić uwagę na to, co wydaje się oryginalne w pracach polskich dotyczących języka przekładu.

Uwagi moje będą tu z konieczności selektywne i subiektywne - bo istotnie byłoby rzeczą trudną przedstawić w krótkim artykule choćby w niewielkiej skali mapę tego, co na temat roli języka w przekładzie ukazało się w Polsce na przestrzeni ostatnich mniej więcej 30 lat. Ale zadanie takie stoi przed nami i jest na pewno warte podjęcia.

Tutaj, odwołując się do książki specjalisty z Helsinek, Andrew Chestermana, chciałabym najpierw podkreślić to, co stanowi według niego część pewników (Chesterman 1997: 2) i co zdaje się mieć ogólną akceptację. Jest wśród nich przede wszystkim przekonanie, iż zadaniem thumacza jest przekazywać i rozwijać język i elementy kultury. Następne jego tezy to przyjęcie metafory tekst źródłowy / tekst docelowy, idei ekwiwalencji, mitu o nieprzekładalności, rozróżnienia tłumaczenia swobodnego i dosłownego, wreszcie także stwierdzenie, że wszelkie pisanie jest rodzajem tłumaczenia. Problematykę tę można też ująć trochę inaczej:

- Współczesne przekładoznawstwo jest dziedziną interdyscyplinarną, na styku dyscyplin takich jak językoznawstwo, psychologia, antropologia, teoria literatury, komparatystyka literacka, i samo nie będąc „nauką”, korzysta z osiągnięć i propozycji innych nauk.

- Tłumaczenie tekstów artystycznych pełni doniosłą rolę w przenikaniu się kultur i równocześnie w rozwoju i kształtowaniu języka - i ta myśl jest oczywiście ważniejsza, niż zatrzymywanie się, powierzchowne przecież, np. na krytyce tego, co w przekładach jest niepoprawne.

- Funkcja thumaczenia pojmowana jest albo, np. za Romanem Jakobsonem, jako odtwarzanie nadorganizacji językowej, albo jako rekonstrukcja wyobrażonej i przedstawionej rzeczywistości. Ale ostatnio takie rozumienie funkcji tłumaczenia poddawane jest w wątpliwość, i np. Joanna Kokot (Kokot, 2000: 365) stawia pytanie o dopuszczalność własnych propozycji tłumacza i tym samym przypomina o możliwości dokonywania przeobrażeń w języku przekładu. 
- Przyjmuje się też na ogół i podkreśla aspekt komunikacyjny tłumaczenia: wiadomo od zawsze, że tłumaczy się, aby przekazywać sens. Ale ten pewnik, przekonanie, że przekład ma przekazywać „komunikat” zawarty w oryginale budzi też oczywiste opory, jako niewystarczający gdy mamy do czynienia z tekstami artystycznymi, na co przecież wskazywał m.in. Stanisław Barańczak. Dawno już temu (1923) protestował przeciw takiemu rozumieniu tłumaczenia artystycznego Walter Benjamin, podkreślając, iż dla niego „przekład to forma” (Benjamin 1975: 294).

Tej właśnie w gruncie rzeczy banalnej myśli, iż w tłumaczeniu tekstów literackich ważny jest przekaz formy, czy jak powie francuski filozof i thumacz Antoine Berman, „litery tekstu”, chciałabym się przyjrzeć nieco bliżej, opierając się na kilku wybranych pracach polskich - i równocześnie sięgając skrótowo do propozycji innych autorów. Dlatego w ostatnich polskich przemyśleniach dotyczących języka przekładów oraz sposobów tłumaczenia, bardziej niż rozważania nad przystawalnością strukturalną języków oraz tworzonych w nich obrazów świata, bardziej też niż refleksja nad stopniem przekładalności czy nieprzekładalności chociaż problemy te są bardzo ważne - interesują mnie te uwagi, które dotyczą czegoś, co określane jest bardzo rozmaicie: jako obcość w przekładzie, światło między językami, także jako egzotyzacja, choć określenia te nie są synonimiczne. Zajmę się zatem szeregiem opracowań opublikowanych w Polsce w ostatnich latach, w których pojawia się to, na co pragnę zwrócić tu uwagę: zagadnienie obcości w języku przekładu.

Najpierw kilka słów o egzotyzacji w pracach polskich. Jest to, pisze Roman Lewicki, „w naszym rozumieniu procedura nakierowana na strategiczne wprowadzanie obcości. [...] Przyjęcie przez tłumacza postawy egzotyzacyjnej powoduje, że stara się on w miarę swych możliwości >>przenieść odbiorcę przekładu do kraju oryginału<<" (Lewicki 2000: 193). Rozróżnia on egzotyzację jako strategię thumacza, pozostającą w opozycji do innej strategii, mianowicie adaptacji - oraz obcość, którą się aktywizuje, której nośnikami są egzotyzujące sposoby tłumaczenia, która więc nie jest strategią, lecz rezultatem działania tłumacza. Traktuje on obcość jako kategorię, która

a) jest immanentnie obecna jako gatunkowa własność tekstu przekładu,

b) stanowi „próbę rozszerzenia systemu JP [języka przekładu] w kierunku zbliżenia do systemu JO [języka oryginału],

c) uzewnętrznia się denotatywnie, odwołując się do wiedzy odbiorców oraz konotatywnie, ponieważ opiera się „na zjawisku ewokacji skojarzeń z innym środowiskiem” (Lewicki 2000: $157-158)$. 
W pracach, które poświęca badaniu obcości, interesuje go ona na poziomie faktów językowych „egzotyzujących”, głównie natury leksykalnej i frazeologicznej. Mam jednak zastrzeżenia do prób utożsamiania techniki i jej rezultatów i do traktowania egzotyzacji tłumaczenia i obcości jako pojęć synonimicznych - a taką opinię można wyczytać m.in. w wydanej ostatnio Terminologii ttumaczenia (Tomaszkiewicz 2004: 106).

Termin ,światło” przypomniany został przez Bożenę Tokarz. Użył go Benjamin, pisząc:

Prawdziwy przekład jest przeźroczysty, nie przesłania oryginału, nie pozbawia go światła, lecz czysty język, niejako wzmocniony przez swe własne medium, tym jaśniejszym snopem rzuca światło na oryginał (Benjamin, 1975: 303). Światło powstające między dwoma językami w przypadku dobrych tłumaczeń wzbogaca obszar niewypowiedzianej, lecz obecnej w różnych kontekstach i sytuacjach informacji”, bo światło jest tym, co „niewypowiedziane już w granicach jednego języka (Tokarz 2000: 16).

Oznacza to, że języki oświetlają się wzajemnie i są spokrewnione w tym, co chcą wyrazić.

Międzyjęzykowe światło odkrywa inne możliwości poznawcze i sensy, nie niszcząc tożsamości. [...] W świetle międzyjęzykowym znajduje się całość doświadczenia mentalnego autora i tłumacza, których ekspresją jest konkretna konceptualizacja literacka (Tokarz 2000: 11).

W przekładach, sądzi ona, powinno się więc

zwrócić uwagę na rodzaj kontaktów między językami, nie tylko na te, które wynikają $\mathrm{z}$ porównania systemów, lecz także na takie, w których jeden język narzuca, lub proponuje drugiemu pewien wzorzec, literatura bowiem zwielokrotnia możliwości, jakie tkwią w języku i rozszerza semantykę form językowych, zwłaszcza ich wieloznaczność (Tokarz, 1998: 146).

Przykładem mogą być „formy zbliżone do francuskiego subjonctif w postaci konstrukcji zdaniowych z użyciem czasowników modalnych” (Tokarz 1998: 143-147). Światło, pisze ona dalej, powstaje w skutek relacji „wewnątrz wypowiedzi i między nimi... nie tyle w strukturze języka, ile w strukturze tekstu” - całości o różnym stopniu złożoności (Tokarz 1998: 14). Pominę tu jej dalsze rozważania, które koncentrują się na związkach między literaturami i kulturami i powrócę do „obcości” i jej przejawów w języku przekładu.

By zająć się terminem „obcość”, trzeba jeszcze zwrócić uwagę na te rozważania Benjamina, które od refleksji nad światłem, dotyczącym doświadczenia mentalnego i znaczenia, każą zwrócić się do roli języka w przekładzie. Podkreślał on mianowicie, że zadaniem tłumaczenia - można się zgodzić, że nie jedynym - jest przekształcanie języka przekładu przez harmonijne połączenie dwóch różnych sposobów znaczenia (por. Bracken 2002). Słowo jest siłą kreatywną, która nie przekazuje, lecz czyni znaczenie; w słowie forma komunikuje samą siebie, a nie coś, co istnieje poza nią. To odwrócenie tezy Saussure’a o arbitralności znaku oznacza, iż relacja między słowem i rzeczą nie jest ustalona przez 
konwencję. Słowa tworzą sens, który w akcie tłumaczenia powstaje po to, by wywoływać podobieństwo, uczestniczyć w nazywaniu rzeczy. Dlatego nazwa, czyli wybór słowa, nie jest sprawą przypadku. Benjamin twierdził także, że język jako akt kreatywny przeciwstawia się językowi poznania i że to, co słowo mówi o rzeczy naśladuje to, co rzecz mówi sama o sobie. Jeśli nawet nie jest to $\mathrm{w}$ pełni jasne, myśl Benjamina kieruje naszą uwagę na to, co „niewypowiedziane” i szerzej także na pojęcie „prawdy thumaczenia”, która nie polega na „adekwatności” wobec oryginału, wobec jego nieruchomej fasady, lecz, jak powie za Benjaminem Antoine Berman, stanowi zerwanie z orientacją na język i kulturę docelową ( $\mathrm{z}$ „etno-centrycznością” tłumaczenia). Prawda ma polegać na wprowadzeniu tego, co „obce”.

Tu chciałabym przypomnieć opinię wspomnianego już Bermana o obcości w tłumaczeniu, o épreuve de l'étranger, przez którą rozumie on ukazanie i tego, co jest obce $\mathrm{w}$ dziele, i tego, co stanowi doświadczenie samej obcości dzieła, oderwanego od własnej gleby.To oderwanie, pisze Berman, ma „ujawnić, w dziele obcym, jego jądro najbardziej oryginalne, najbardziej ukryte, najbardziej własne i zarazem najbardziej $>>$ obce $<<"$ ". I to właśnie stanowi według niego ,aspekt etyczny” aktu tłumaczenia: „przyjąć obce jako obce” (Berman 1985a). Benjamin mówił, iż przekład jest echem oryginału i zadaniem thumacza jest ustalenie „takiej formy językowej, w której odezwałoby się” to echo (Benjamin 1975: 300). Tokarz też pisze o tym wyraźnie (Tokarz 1998: 16): „[p]rzekład rozumiany jako inwariant oryginału musi oznaczać zmianę substancji oznaczającej” - czyli właśnie tzw. formy. „Światło” w przekładzie oznacza więc położenie akcentu i twórcze przeniesienie owej „substancji oznaczającej”, co dotyczy jej zdaniem zwłaszcza dosłowności składni. Złożoności tekstu nie wyczerpuje składnia - choć właśnie na problematykę składni będzie zwracał uwagę mój przykład nr 2. „Wyjątkowa złożoność tekstu literackiego - pisze dalej Tokarz - wynika potencjalnie ze struktur uczestniczących w procesie translacji języków”. Szczególną uwagę zwracają takie różnice między dwoma językami jak: możliwość znalezienia ekwiwalentyzacji ze względu na odmienną kategoryzację świata, sposób osiągania spójności sensu, ramy poznawczo-interakcyjne, czy stopień informacyjności. Do tej listy dodam też różnice natury retorycznej.

Trzeba stwierdzić, że dla Bermana „obcość” w tekście przekładu oznacza otworzyć to, co obce i ujawnić nową jakość, przyjąć Inne jako Inne, czyli „otworzyć Obce jako Obce na własną przestrzeń językową” oraz podjąć z nim dialog, który ukaże ,prawdę” w thumaczeniu. Obcość bowiem wiąże się z pojęciem „etyczności” tłumaczenia. Oznacza to, referuję jego poglądy (Berman 1985b: 88-89), skupienie się na literze dzieła (np. na ikoniczności), na jego „substancji oznaczającej” jak powie Tokarz. Celem takiego tłumaczenia ma być to, co Goethe 
nazywał Verjüngung, „odmłodzenie języka”, jak podobnie twierdził już Humboldt, mówiąc, iż przekład ma być „obcy” i ma odmładzać język. Berman przywołuje wśród przykładów przekład Hölderlina, który tłumacząc Antygonę Sofoklesa dokonywał „gwałtu” na języku niemieckim, w epoce Bildung, tworzenia kultury niemieckiej przez Niemcy romantyczne. Chodzi o to, że zamiast upiększania, Hölderlin żądał tłumaczenia archi-dosłownego, traktował tłumaczenie jako miejsce walki, mające ujawnić to, co było ukryte, „tajemne” w oryginale - i jest to gwałt, bo tłumaczenie skupiające się na literze zbliża język przekładu do języka oryginału; w konsekwencji greka wzbogaca poprzez przekłady Sofoklesa język niemiecki. Tłumaczenie literalne Hölderlina - twierdzi dalej Berman - odnajduje i przenosi znaczenie pierwotne niektórych wyrazów greckich i także wraca do znaczenia pierwotnego słów niemieckich, do języka Lutra (Berman 1985b: 102), Hölderlin bowiem pragnął odtworzyć ton, Grundton, poprzez tłumaczenie „literalne” i etymologizujące. Berman podkreśla dalej, że wraz z Hölderlinem pojawia się pojęcie ,prawdy tłumaczenia, która nie jest już „adekwatnością” wobec oryginału, wobec jego „nieruchomej fasady” (Berman, 1985b: 107), lecz ma stanowić „akt etyczny”.

Rolę aktu etycznego ilustruje Berman także innym przekładem, mianowicie FrançoisRené Chateaubrianda The Paradise Lost, „Raju utraconego”, Johna Miltona na język francuski. Chateaubriand podjął mianowicie tłumaczenie dosłowne, jednak nie ,słowo-wsłowo", lecz takie, które violente, zadaje gwałt językowi przekładu (chodzi o naruszanie składni, np. pomijanie rodzajników, zmianę walencji czasowników, tworzenie neologizmów, używanie archaizmów, także zostawianie tego, co w oryginale jest niejasne, np. cytaty z Apokalipsy). Berman stwierdza, że u Chateaubrianda „Język przekładu odpowiada dwu językom oryginału, angielskości i łacińskości, dzięki, jak pisze, podwójnej dosłowności, składniowej, także leksykalnej i fonicznej”. Chateaubriand zerwał z tradycją etnocentryczną i hipertekstową dominującą przed nim w tłumaczeniach francuskich. Jego przekład jest przykładem „wolty hölderlinowskiej”, zwrotu ku własnemu językowi i kulturze i ,nie jest to genialne przetworzenie (jak u Nervala i Baudelaire'a), lecz trudna i niewdzięczna praca nad literą" (Berman 1985b: 123-124).

Przewijająca się u polskich przekładoznawców myśl o wzbogacającej roli języka, który wzmacnia poetykę rodzimą, jest w stosunku do koncepcji Benjamina, i także Bermana, myślą stonowaną, chyba nie tak kategoryczną, nie tak ostro kładącą nacisk na dominującą rolę języka i owo światło, które w tłumaczeniu jeden z języków rzuca na drugi język. Bo Benjamin pisał także, że „przekład jest jakby doraźnym sposobem rozprawienia się z odmiennością języków”. Równocześnie „stosunek treści do języka jest w oryginale zupełnie inny niż w przekładzie. 
Jeśli bowiem w oryginale stanowią one pewną jedność, jak owoc i łupina, to język przekładu okrywa treść niczym królewski płaszcz, luźno układający się w szerokie fałdy. Przerasta on przekład, a przez to jest nieadekwatny do treści, przygniatający i obcy” (Benjamin 1975: 299$300)$.

Tę myśl odnajdujemy w nieco innej formie w polskich badaniach, które traktują przekład jako doświadczenie dwujęzyczności w literackiej strukturze semantycznej. Rolę przekładów dla rozwoju języka i kultury podkreśla wyraźnie Edward Balcerzan, gdy przedstawia rozmaite koncepcje teoretyczne thumaczenia. Jego zdaniem istnieją koncepcje: antropologiczna (tłumaczenie to akt przenoszenia informacji, zależny od sposobu postrzegania świata), lingwistyczna, rozróżniająca plan wyrażania i plan treści i wtedy tłumaczenie zmienia plan wyrażania, zachowując plan zawartości i literacką, dla której, jak pisze Balcerzan:

Językowe elementy planu wyrażania mogą stanowić główną zawartość poematu czy powieści.(..) Wiele rozmaitych definicji tłumaczenia literackiego krąży wokół idei przekładu jako rekonstrukcji strukturalnej, wykonanej nie tylko w obcym dla pierwowzoru języku etnicznym, ale także w znakach innej tradycji literackiej (wierszowej, stylistycznej, gatunkowej, itd.) (Balcerzan, 1998: 25).

Można dopatrzyć się częściowej zbieżności jego koncepcji z myślą Bermana, choć nie wiadomo, czy badacz poznański by się na to zgodził, gdy np. w rozdziale „Wobec tradycji” pisze, iż tłumaczenie, podjęte z pozycji, którą nazywa ,redundantną”, wzmacnia poetykę rodzimą: „Niejednokrotnie tłumaczenia przyjmują wyznaczniki stylów rodzimych, które ukształtowały się $\mathrm{w}$ jakimś minionym okresie historycznoliterackim. Tłumaczony przez Juliana Tuwima Eugeniusz Oniegin Aleksandra Puszkina wzbogacił przede wszystkim polską tradycję stylu romantycznego”. Szczególnie interesujące dla problematyki „światła” i obcości wydają się uwagi Balcerzana o „odkryciu stylu”, czyli o „pozycji innowacyjnej” w tłumaczeniu, polegającej na „przeciwstawianiu się kanonom stylistycznym języka rodzimego” (Balcerzan 1998: 97 i nast.). Balcerzan zwraca następnie uwagę na istnienie „barier językowych w rekonstrukcji stylu dzieł obcojęzycznych” i na przełamywanie przez thumaczy kodu, a więc tym samym na rolę owego „królewskiego płaszcza” - gdy np. Tuwim stosuje „kalkę stylistyczną”, twórczą innowację, proponując neologizm „zaumni” (Balcerzan 1998: 104-105).

Myśl tę, o barierach językowych, rozwija i dopowiada Elżbieta Tabakowska, podkreślając rolę tłumacza jako mediatora miedzy dwiema kulturami oraz ujmując problematykę języka w przekładzie z punktu widzenia językoznawstwa kognitywnego. Podkreślając, że „zmieniony (...) sposób mówienia o rzeczywistości prowadzi do zmiany w obrazie świata" (Tabakowska 
2002: 33), określa jako imperialistyczną postawę tłumacza, który „tworzy obraz świata analogiczny do obrazu zakodowanego w języku oryginału”. Otóż tutaj interesuje mnie właśnie ów imperializm w języku przekładu, z tym, że chciałabym zatrzymać się na poziomie języka i obcości w przekładzie, pozostawiając niejako na uboczu wynikającą z obcości interpretację kulturową.

Jak o obcości w przekładzie mówią inne opracowania polskie?

Piotr Kwieciński (2001) przeciwstawia pojęcia obcości i udomowienia. To ostatnie, powołując się na Venutiego (Venuti 1992, 1995), rozumie jako „dostosowanie tekstu docelowego do pojęć, norm i konwencji zastanych w kulturze docelowej”, wyobcowanie zaś jako „wprowadzenie do tekstu docelowego pojęć i form językowych obcych i/lub nieprzejrzystych w kulturze i języku docelowym, podważające i zakłócające kody kulturowe języka docelowego”. Takie właśnie zjawisko - pisze dalej Kwieciński - Berman opisuje jako „obcość zakłócającą, burzącą spokój, domowość i naturalność języka docelowego”. Kwiecińskiego interesują jednak dalej raczej, jak się zdaje, procedury egzotyzujące, które, jak pisze, mogą „w pełni czy w dużym stopniu odpowiadać normom i konwencjom języka i kultury docelowej” (Kwieciński 2001: 257-8). Tytułem ilustracji „udomowienia”, chciałabym przywołać przykład zwrotu i obrazu biblijnego safaqti 'al. jarek, 'uderzyłem się po biodrach', który autor ciekawej rozprawy o „Grzechu dosłowności...” każe przełożyć jako 'uderzyłem się w piersi', gest uderzania się po biodrach miał bowiem znaczenie żalu (Piela 2003: 16).

Refleksję nad obcością burzącą spokój prowadzi dalej Roman Lewicki, podkreślając, że obcość wynika z językowej i kulturowej wtórności przekładu, z jego samej istoty. Wśród cech przekładu wywołujących odczucie obcości wymienia on na pierwszym miejscu odmienność językową, co jest oczywiste - i dalej odmienność kulturową oraz religijną i aksjologiczną (Lewicki 2002: 46). Zwraca uwagę w jego artykule podkreślenie roli odbiorcy, akceptującego obcość, lub przeciwnie odrzucającego „szok kulturowy” i językowy.

Tytułem dygresji trzeba wspomnieć o rozważaniach Lawrence'a Venutiego na temat „totalitaryzmu” (Venuti 2001: 9), procesu oswajania tekstu, który uważa za krok w stronę ułatwionej czytelności (33), gdy obcość polega na wprowadzaniu różnic i stanowi według niego literacką i kulturową „nadwyżkę” (Venuti 2001: 22). Oczywiście warto przeczytać Venutiego, i chyba zwłaszcza jego The Translator's Invisibility (Venuti 1995). Nie można jednak nie zauważyć - tak jak to zrobił Anthony Pym w bardzo ironicznej recenzji (Pym 1996; por. także uwagi Jolanty Kozak 2001), że obcość pojmuje Venuti specyficznie, jako akt agresji, mający według niego daleko idące konsekwencje ideologiczne, które jak się zdaje interesują go najbardziej i chyba aż do przesady - podczas gdy, zdaniem Pyma, analiza 
obcości w języku przekładów, przeprowadzona solidnie, mogłaby raczej zwracać uwagę na wielokulturowość Ameryki i służyć jej zrozumieniu i akceptacji (Pym 1996: 175). Agresję rozumie Venuti $\mathrm{w}$ sensie hermeneutycznym, jako jedną $\mathrm{z}$ faz modelu hermeneutycznego zaproponowanego przez Steinera. Można więc zatrzymać się na tym etapie i potraktować ów „imperializm”, o którym wspomina Elżbieta Tabakowska oraz „agresję” Steinera i Venutiego jako Jakobsonowskie „łamanie kodu” językowego i wtedy wracamy do problemu obcości w duchu Benjamina i Bermana, najjaskrawiej widocznego na przykładzie Hölderlinowskiej Antygony i jego „niemieckiej greki”; Olga i Wojciech Kubińscy piszą o tym przypadku jako o tworzeniu przez przekład nowej jakości językowej (Kubińscy 2000: 682).

Wracając zatem do problematyki światła, egzotyzacji i szerzej, obcości w języku przekładu, wydaje się, że ukazuje ona stosunkowo mało wyeksploatowane horyzonty badawcze. Za ważną uznać można przede wszystkim rolę przekazywania obcości w języku dla wzbogacania języka przekładu i także dla ukazywania tego, co Berman nazywał „prawdą” w thumaczeniu.

Jako ilustracja mogłyby posłużyć polskie przekłady Madame Bovary Gustawa Flauberta (trzy różnego autorstwa oraz szereg przekładów studenckich), i w powieści tej m.in. przekład wyjętego z całości przemówienia radcy uświetniającego swoją obecnością wiejski zjazd rolniczy. W jakim mianowicie stopniu thumacze zachowali obcość wzbogacającą, a niekoniecznie udziwniającą? Zwracają bowiem uwagę różne u każdego z nich sposoby oddania organizacji retorycznej, która jest tak istotna dla „stylu oratorskiego” autora powieści. Flaubert posługuje się często powtórzeniem, repetitio, oraz jego szczególną formą, jaką jest wyliczenie, enumeratio. Bywa to u niego tzw. zgrupowanie potrójne, trzykrotne użycie tego samego schematu - powtórzenie-wyliczenie, przy czym ostatni element wyliczenia jest najdłuższy i ewentualnie, co także znamienne, dodatkowo wprowadzony przez spójnik et. Amplifikacje, powtórzenia i wyliczenia służą m.in. nasycaniu dyskursu elementami oratorstwa politycznego, argumentacją wartościującą, antytezami (dobro-zło). Wobec takiego bogactwa użytych środków tłumacze polscy wydają się czasem bezradni i usiłują nadać przemówieniu wygląd bardziej swojski, „upraszczając” np. redundancję wyliczeń. To „udomowienie” zdaje się wynikać z niezrozumienia „litery” tekstu, także z braku, być może, kompetencji retorycznej - wszak wśród czynników ograniczających działania tłumacza, Tokarz wymienia m.in. możliwości wynikające z procesu historycznego oraz „nawyki i upodobania literackie odbiorców” (1998: 65). Jeśli więc miałabym kontynuować krytykę negatywną, powiedziałabym, że za ewentualne uchybienia odpowiada $\mathrm{w}$ wielu wypadkach horyzont tłumaczy, ich zapewne niewyćwiczone ucho, ich być może niewystarczające oczytanie w 
prozie francuskiej i przede wszystkim polskiej i stąd bierze się uleganie tendencji etnocentrycznej i przykrawanie materii językowej do wyimaginowanego ideału „wierności”. Ale równocześnie, projekty tłumaczenia, które można np. odczytać w niektórych przekładach studenckich, świadczą jednak o wahaniach i o poszukiwaniu śmielszych rozwiązań, bardziej zorientowanych na zachowanie obcości. Wartość przekładów polega właśnie na próbach przełamywania schematów, szukania rozwiązań oryginalnych - jak np. rymowane wyliczenie $\mathrm{w}$ jednym z przekładów, a więc zachowanie i figury retorycznej (enumeratio) i chwytu stylistycznego (rym), czy np., na poziomie i retoryki i słownictwa przełożenie wyrażenia le char de l'état jako 'rydwan państwa', co pozwala zachować antytezę i tym samym ratować „obcość” w przekładzie.

Drugim przykładem, wskazującym na świadomą intencję „,rzucenia światła” na obcość, nie tylko na egzotykę języka może być bardzo interesujący projekt tłumacza na język polski powieści Zazie dans le métro, której fragment znajduje się w Aneksie. Kreatywność i oryginalność pomysłu tłumacza polega tu na próbie odtworzenia wieloznaczności i swoistej wielojęzyczności powieści Raymonda Queneau (bo pisarz zestawia rozmaite rejestry języka) i na wysiłku, by przekład robił wrażenie swoistej „francuskości”. Wszak „rewolucja językowa” zaproponowana przez Queneau dotyczy wszystkich poziomów języka. Zastosowane przez thumacza transformacje, ukazane w załączonym fragmencie (,Zazie w metrze”, Rzepka 2002, 4), zwracają uwagę na rozmaitość faktów językowych, które w oryginale naruszają system języka francuskiego. W przekładzie świadczą one o próbach przekazania „ducha” (génie) języka francuskiego i dotyczą słownictwa, np. walicha czy taksa, ortografii, np. fyjaśniać, tóra czy wykszyknęta, budowy wyrazów, np. lewam to albo zumiałaś? i przede wszystkim składni, zdanie Ja go nam zarezerwowaliśmy, doktadnie z powodu strajku, tę jego takse jest niepoprawne tą niepoprawnością gramatyczną, której nie rejestruje gramatyka polska i której chyba nie stosują polscy powieściopisarze, preferujący, jak się zdaje, wulgaryzmy i na poziomie składni elipsę. Oczywiście, powstaje pytanie, czy warto tak dalece wyobcowywać przekład powieści Queneau. Nie można jednak nie zauważyć, że próba taka jest interesująca, ukazuje bowiem inny, francuski, a więc obcy w tradycji polskiej, model języka mówionego. Nie chodzi w nim wyłącz-nie o egzotyzację, o kalkowanie wyrazów i zwrotów, ale o pełniejszą próbę przejęcia obcego wzoru „substancji oznaczającej” i oryginalnego zastosowania go do materii powieści, na poziomie słowotwórstwa, ortografii i zwłaszcza składni.

Można by, podsumowując, zastanowić się nad sensownością hipotezy, którą Piotr Kwieciński nazwał probabilistycznym prawem interferencji, głoszącą, że „w słabych kulturach 
docelowych, gdzie przekład zajmuje pozycję centralną, proporcjonalnie wysoka jest tolerancja form wyobcowujących” (Kwieciński 2001: 259). Można też przywołać na zakończenie myśl cytowanego już Grosbarta, który stwierdził, że istnieją przekłady asekuranckie oraz, w przeciwieństwie do nich przekłady odważne, „które swoje pierwowzory wzbogacają (Giaur Mickiewicza, Grenada Swietłowa, czy rosyjskie thumaczenie fragmentu „Talmudu”)... Zarysowuje się tu istotny dla tłumaczy i krytyków problem, który proponuję zdefiniować jako Zuchwałosć i nieśmiatość w ttumaczeniu" (Grosbart 1999: 22). Przekład Tomasza Rzepki należy do zuchwałych, podczas gdy przekłady Pani Bovary mieszczą się na linii, która wiedzie od najbardziej do stosunkowo mało nieśmiałych.

\section{Źródlo}

Powyższy tekst po raz pierwszy ukazał się w 2005 roku w tomie Konteksty przekładowe pod redakcją Marii Piotrowskiej, Język a komunikacja 8, Kraków: Wydawnictwo Tertium; 183195.

\section{Aneks}

Fragment powieści Raymonda Queneau, Zazie dans le métro, Paryż: Gallimard (2000).

- Tonton, qu'elle crie, on prend le métro?

- Non.

- Comment ça, non?

Elle s'est arrêtée. Gabriel stope également, se retourne, pose sa valoche et se met à espliquer. - Bin oui: non. Aujourd'hui, pas moyen. $\mathrm{Y}$ a grève.

- $\mathrm{Y}$ a grève.

- Bin oui: y a grève. Le métro, ce moyen éminemment parisien, s'est endormi sous terre, car les employés aux pinces perforantes ont cessé tout travail.

- Ah les salauds, s'écrie Zazie, ah les vaches. Me faire ça, à moi.

- Y a pas qu'à toi qu'ils font ça, dit Gabriel parfaitement objectif.

- Jm'en fous. N'empêche que c'est à moi que ça arrive, moi qui qu'étais si heureuse, si contente et tout de m'aller voiturer dans lmétro. Sacrebleu, merde alors.

- Faut te faire une raison, dit Gabriel dont les propos se nuançaient parfois d'un thomisme légèrement kantien.

Et, passant sur le plan de la cosubjectivité, il ajouta: - Et puis faut se grouiller: Charles attend.

- Oh! celle-là je la connais, s'esclama Zazie furieuse, je l'ai lue dans les Mémoires du général Vermot.

- Mais non, dit Gabriel, mais non, Charles, c'est un pote et il a un tac. Je nous le sommes réservé à cause de la grève précisément, son tac. T'as compris? En route. 
Il resaisit la valoche d'une main et de l'autre il entraîne Zazie.

Przekład polski, niedrukowany: Tomasz Rzepka, „Zazie w metrze” (2002: 4):

- Wujciu - tak krzyczy - pojedziemy metrem?

- Nie.

- Jak to nie?

Zatrzymała się. Gabriel też staje, odwraca się, kładzie walichę i zaczyna fyjaśniać.

- Więc tak: nie.

Dziś nie da rady. Jest strajk.

- Jest strajk.

Więc tak: jest strajk. Metro, środek transportu wybitnie paryski, zasnęło pod ziemią, bo panowie z dziurkaczami przestali pracować.

- O łotry! - krzyczy Zazie. - O bydlaki! Zrobić mi coś takiego!

- Nie tylko tobie to robią - mówi skrajnie obiektywny Gabriel.

- Lewam to. Ale spotyka to mnie, tóra byłam taka szczęśliwa, zadowolona i w ogóle, że będę mogła się przejechać metrem. Kurczę, cholera jasna.

- Musisz się z tym pogodzić - mówi Gabriel, w którego słowach pobrzmiewała czasem nutka lekko kantowskiego tomizmu. I, przechodząc w sferę kosubiektywizmu, dorzucił:

- A poza tym trza się uwijać: Karol czeka.

- Och! Ona, znam ją - wykszyknęła wściekła Zazie - czytałam ją w pamiętnikach generała Vermota.

- Nie nie - powiedział Gabriel - nie nie. Karol to mój kumpel, - który ma taksę. Ja go nam zarezerwowaliśmy, dokładnie z powodu strajku, tę jego taksę. Zumiałaś? W drogę.

Jedną ręką chwycił walichę, a drugą Zazie.

\section{Bibliografia}

Balcerzan, Edward (1998) Literatura z literatury. Katowice: Wydawnictwo Naukowe ,Śląsk”.

Benjamin, Walter ([1923] 1975) „Zadanie thumacza” ([Die Aufgabe des Übersetzers] (thum.) Janusz Sikorski. [W:] Twórca jako wytwórca. Poznań: Wydawnictwo Poznańskie; $293-$ 324.

Berman, Antoine (1985a) „La traduction comme épreuve de l'étranger”. [W:] Texte 4; 6781 .

Berman, Antoine, Gérard Granel, Annick Jaulin (1985) Les Tours de Babel: essais sur la traduction. Mauvezin: Trans-Europ-Repress. 
Berman, Antoine (1985b) „La traduction et la lettre ou l'auberge du lointain”. [W:] Berman, Antoine, Gérard Granel, Annick Jaulin, Les Tours de Babel: essais sur la traduction. Mauvezin: Trans-Europ-Repress; 35-150.

Bracken, Christopher (2002) „The language of things: Walter Benjamin's primitive thought”. . [W:] Semiotica 138;. 321-349.

Chesterman, Andrew (1997) Memes of Translation. Amsterdam-Filadelfia: John Benjamins. Grosbart, Zygmunt (1998) „Przesłanki opracowania ‘użytecznej’ teorii przekładu”. [W:] (red.) Piotr Fast Przeklad artystyczny. Katowice: Wydawnictwo Śląsk; 47-55.

Grosbart, Zygmunt (1999) „Cóż to jest przekład? Pytanie prawie mistyczne”. [W:] (red.) Piotr Fast Krytyka przekładu w systemie wiedzy o literaturze. Katowice: Wydawnictwo Śląsk; 723.

Kahn, Robert (1998) Images, passages: Marcel Proust et Walter Benjamin. Paryż: Kimé.

Kokot, Joanna (2001) „Przekład literacki. Tekst i konteksty”. [W:] (red.) Olga Kubińska, David Malcolm Paradoksy Humanistyki, Księga pamiątkowa ku czci prof. A. Zgorzelskiego. Gdańsk: Wydawnictwo Uniwersytetu Gdańskiego; 167-179.

Kozak, Jolanta (2001) „Lawrence Venuti, czyli o przekładach oswojonych i wyobcowanych”.

[W:] Przektadaniec 8; 43-51.

Kwieciński, Piotr (2001) Disturbing Strangeness. Toruń: Edytor.

Kubińscy, Olga i Wojciech (2000) „Słowo od tłumaczy”. [W:] George Steiner Po wieży Babel. Problemy języka i przekładu (tłum. Olga i Wojciech Kubińscy). Kraków: Universitas; $678-685$.

Lewicki, Roman (2000) „Między adaptacją a egzotyzacją: The Pickwick Papers w przekładzie polskim i rosyjskim”. [W:] Przekładając nieprzekładalne (red.) Wojciech Kubiński, Olga Kubińska, Tadeusz Wolański. Gdańsk: Wydawnictwo Uniwersytetu Gdańskiego; 191-200.

Lewicki, Roman (2000) Obcość w odbiorze przekładu. Lublin: Wydawnictwo Uniwersytetu Marii Curie-Skłodowskiej.

Lewicki, Roman (2002) „Obcość w przekładzie a obcość w kulturze”. [W:] (red.) Roman Lewicki Przekład, język, kultura. Lublin: Wydawnictwo Uniwersytetu Marii CurieSkłodowskiej; 43-52.

Piela, Marek (2003) Grzech dosłowności we współczesnych przekładach Starego Testamentu.

Kraków: Wydawnictwo Uniwersytetu Jagiellońskiego

Pym, Anthony (1996) „Venuti’s Visibility”. Target 8:1; 165-177.

Rzepka, Tomasz (2002) Limites de la traduisibilité. Problèmes concernant la traduction de 
Zazie dans le métro de Raymon Queneau. [Praca magisterska oraz integralny przekład: Zazie $w$ metrze, maszynopis].

Tabakowska, Elżbieta (2002) „Bariery kulturowe są zbudowane z gramatyki”. [W:] (red.)

Roman Lewicki Przekład, język, kultura. Lublin: Wydawnictwo Uniwersytetu Marii CurieSkłodowskiej; 25-34.

Tomaszkiewicz, Teresa (2004) Terminologia tłumaczenia, Poznań: Wydawnictwo Naukowe UAM.

Tokarz, Bożena (1998) Wzorzec, podobieństwo, przypominanie. Katowice: Wydawnictwo „Śląsk”.

Tokarz, Bożena (2000) „Światło między językami, czyli o potrzebie komparatystyki”. [W:] (red.) Piotr Fast, Katarzyna Żemła Komparatystyka literacka a przekład. Katowice: Wydawnictwo „Śląsk”; 7-18.

Venuti, Lawrence (1995) The Translator's Invisibility: A History of Translation. LondynNowy Jork: Routledge.

Venuti, Lawrence (2001) „Przekład, wspólnota, utopia” (tłum. Jolanta Kozak). Przekładaniec $8 ; 9-42$. 